\title{
Exploration of College English Teaching Reform in Application-oriented Universities
}

\author{
Xu Daoping ${ }^{1, a}$, Shen Hongwei ${ }^{1, b}$, Zhao Weihong $^{1, \mathrm{c}}$ \\ ${ }^{1}$ Qingdao Huanghai University \\ Qingdao, China \\ a1142169699@qq.com, bJeremy8181@163.com, ${ }^{\mathrm{c} 194430179 @ q q . c o m}$
}

\begin{abstract}
It is an urgent problem for undergraduates to develop their English practical ability in application-oriented universities. The research on the definition, connotation, basic features and teaching target orientation of the applied university has a direct impact on the direction of applied college English teaching. Through the overall analysis and thinking of English teachers, students, teaching materials and the present situation of the applied university, the elements of Applied Undergraduate College English application ability, language input, skill training, output ability and the cultivation of intercultural communicative competence are researched. The characteristics and training objectives of application-oriented universities are expounded. In view of the present situation of college English teaching, the method of reform improvement is analyzed. In accord with the actual situation of colleges and universities under the conditions, a scientific and reasonable incentive system is established, which is quite a reasonable project and can meet the development needs of teachers.
\end{abstract}

Keywords-application-oriented university; education situation; reform improvement; training

\section{INTRODUCTION}

Since ancient times, the human development and social progress, education has been playing a very important role, such as in the era of knowledge economy before the reform and opening up. Higher education is more directly related to the development of the national economy and the progress of science and technology, especially the English application. As the main body of institutions of higher learning, the faculty plays a decisive role in improving the overall level of education. Application-oriented university is focusing on "application", which can reflect the spirit of the times and social development requirements of talents, quality concept and educational concept as the guide.

As Comrade Deng Xiaoping pointed out that the school can train qualified personnel for socialist construction, the cultivation of all-round development, socialist consciousness and culture of the workers, the key lies in the reform. In order to promote the overall level of higher education, governments in various countries have increased their investment in the institutions of higher learning and raised their salaries, so as to arouse their enthusiasm and stimulate their research potential [1]. One of the most effective way is focusing on the development of application-oriented universities.

\section{THE CONCEPT AND BASIC ELEMENTS OF APPLICATION- ORIENTED UNIVERSITIES}

\section{A. The meaning of application-oriented university}

In the new situation of higher education construction, it is adapted to meet the needs of economic and social development of the new discipline direction, such as professional structure, curriculum system, teaching content, update teaching, teaching methods and teaching skills, which can improve teaching level, cultivating high-quality talents with strong social adaptability and competitive ability. It requires all majors to combine the local characteristics closely, pay attention to students' practical ability and train applied talents, and embody the two words "application" from the teaching system construction, whose core link is practical teaching.

Applied talents is higher school according to the practical need of society culture oriented, practical for the production line of basic theory knowledge and some research creative transformation ability, which means a compound talents among the training of research universities.

\section{B. The characteristics of application-oriented university}

At present, most of the domestic universities especially those applied talents training mode of newly-built universities or the continuation of the old modes, the training aim, teaching plan, training scheme, curriculum setting and teaching mode are not suitable for the cultivation of applied talents. Specific performance can be listed as follows: (1) Training target is fuzzy and easy to go on "the theory" or "specialist" of the old teaching plan. (2) One-sided emphasis on theory teaching means neglecting the cultivation of practice ability, curriculum, and the public basic courses is specialized too much, too little. (3) Teaching is still a continuation of classroom cramming and to improve the practical ability of students.

On the training objectives with the market oriented with a general education as the foundation, it is important to improve their comprehensive ability, to lay the foundation for the students' professional learning and sustainable development. Based on ability, students can combine theory, actual integration, application of knowledge and technology to solve practical problems with their practical ability and certain 
innovation ability, so that students have prominent features of final thick foundation, wide caliber and application [2-4].

\section{The training target of application-oriented university}

Training in teaching plan is the highlight application and practice ability. The teaching plan should increase the proportion of practical teaching, with students' practical ability and ability to solve practical problems and two innovation ability. In order to change the cramming teaching mode and improve cultivate students' professional knowledge conversion ability, design ability, occupation the behavior ability and team cooperation ability, the target should be based on heuristic teaching mode. Through the analysis of ability, the theory and practice teaching system of each specialty are determined respectively, and the two major teaching systems are parallel, integrated and crossed, and the training of application ability is taken as the intersection point and teaching key point. It emphasizes that the profound professional theoretical basis, broad professional knowledge and strong innovative application ability are developed based on general knowledge. Applied talents should be based on the knowledge background of compaction theory, wide caliber on practice oriented, emphasizing the application of talent. There is a fundamental difference between applied talents and operational, applied and skilled talents [5].

\section{BASIC SITUATION OF COLLEGE ENGLISH TEACHERS}

\section{A. The discipline structure of coordinated development}

Taking Scientific Outlook on Development as a guide, and actively adapt to the needs of regional economic and social development, follow the law of development of the law of development of higher education and private colleges and universities, the personnel training is fundamental to teaching as the center, based on skill training, take the quality as the key, for the purpose of employment, to discipline construction, curriculum construction based on with the reform of education and teaching, as the focal point, to team building as the key to investment support to management for the protection, to institutional innovation as the driving force, the implementation of connotation development, characteristic development.

With application-oriented undergraduate education as the main part and the assistance of skilled higher vocational education, we should actively develop master's degree and graduate education. Discipline and specialty orientation can be listed for taking English as the main body and taking medicine as the characteristic, many disciplines, such as work, medicine, management, literature, education and so on, permeate and support each other and develop in a coordinated way.

\section{B. Characteristics of Teachers staff}

Female teachers accounted for a larger proportion of the overall teachers, male teachers in colleges are relatively few. Young and middle-aged teachers are the mainstream, and the old senior teachers in the proportion are less, while the public institutions of teachers are on the contrary. During the teachers' Education in undergraduate and graduate degree, high degree of $\mathrm{PhD}$ are less. Analysis by the research on reasoning problems, teachers of the college is not stable, the talent mobility and senior scholars are less attractive, and the training ability is not enough [6-8].

According to the investigation of the salary, housing and health of teachers, the statistical results are shown in table 1. According to the statistical analysis, we can see that teachers pay more attention to salary and health in the basic physiological needs. In the survey, $73 \%$ of people think about the overall salary, occupy $3 / 4$, and health demand reached $90 \%$; therefore, wages and health needs is the primary problem to be solved at present union college.

TABLE I. BASIC CONDITION OF THE TEACHERS

\begin{tabular}{|c|c|c|c|c|c|}
\hline & $\begin{array}{c}\text { Level 1 } \\
(\%)\end{array}$ & $\begin{array}{c}\text { Level 2 } \\
(\%)\end{array}$ & $\begin{array}{c}\text { Level 3 } \\
(\%)\end{array}$ & $\begin{array}{c}\text { Level 4 } \\
(\%)\end{array}$ & $\begin{array}{c}\text { Level 5 } \\
(\%)\end{array}$ \\
\hline salary & 73 & 20 & 7 & 0 & 0 \\
\hline housing & 65 & 21 & 12 & 2 & 0 \\
\hline health & 90 & 8 & 2 & 0 & 0 \\
\hline
\end{tabular}

According to the investigation, the inner relationship of the statistical results are shown in table 2 . It can be seen that $68 \%$ of the teachers think that they have great inner relationship for other people, which is relatively few.

TABLE II. INNER RELATIONSHIP OF THE TEACHERS

\begin{tabular}{|c|c|c|c|c|c|}
\hline & $\begin{array}{c}\text { Level 1 } \\
(\%)\end{array}$ & $\begin{array}{c}\text { Level 2 } \\
(\%)\end{array}$ & $\begin{array}{c}\text { Level 3 } \\
(\%)\end{array}$ & $\begin{array}{c}\text { Level 4 } \\
(\%)\end{array}$ & $\begin{array}{c}\text { Level 5 } \\
(\%)\end{array}$ \\
\hline relationship & 68 & 21 & 8 & 3 & 0 \\
\hline $\begin{array}{c}\text { sense of } \\
\text { belonging }\end{array}$ & 55 & 20 & 18 & 5 & 2 \\
\hline
\end{tabular}

\section{Main situation and problems}

Survey shows that the school, undergraduate education accounted for $39.9 \%$ of teachers, master's degree accounted for $51.9 \%$, while the doctor's degree of only $8.2 \%$. This shows that there is a lack of highly educated and experienced teacher resources. The low level of teacher education will lead to insufficient academic level and weak scientific research ability, thus affecting the long-term development of the college.

Lower basic salaries will result in large numbers of teachers taking classes and ensuring their income through class allowances. The teacher will be a lot of time devoted to teaching, the research time and energy naturally declined, in the long run, this will make the teaching quality and academic level of colleges and universities is stagnant, affect the longterm development of the school.

\section{REFORM AND IMPROVEMENT OF COLLEGE ENGLISH TEACHING BASED ON INCENTIVE SYSTEM}

In accord with the actual situation of colleges and universities under the conditions, to establish a scientific and reasonable incentive system is a quite a reasonable project, which meet the development needs of teachers. During the premise of system establishing, the incentive system is to play the role of skill based on motivation needs arising from teachers' work. Harmonious interpersonal relationship between the working conditions in the atmosphere by the 
harmonious, the people, the environment and the formation of teachers' positive attitude is the direct result of teachers' incentive system to play a key role. Higher education is a special group, so in the construction of the incentive system, we must consider the comprehensive, should also consider the difference between teachers and teachers' incentive mechanism should not only be able to play a long-term effect, but also to see the incentive effect in the short term.

\section{A. The basic principles to follow}

The concept of "teachers first" management concept means that some teacher cannot sum up the needs of a certain level as the needs of all teachers. There are differences between teacher, and the needs of the same person in different stages are different. Therefore, in the construction of incentive scheme, should give full consideration to this point, the incentive method to meet the individual needs of It differs from man to man., the most urgent as the starting point, the integrated use of a variety of incentive methods, to maximize its incentive effect.

In the process of demand incentive target to guide the mental health, and their mental balance, establish the scientific concept of fair value, make its realize is not absolutely fair, do not compare with others, only through their own efforts to improve their ability to closer distance and relative fairness criteria. Only by formulating a relatively fair and reasonable incentive system, can the incentive system play its role, stimulate the potential of teachers and promote the development of institutions of higher learning [9].

The system has the characteristics of difference, competition and timeliness, according to the above characteristics in the construction of Union College need scientific and reasonable incentive system of teachers from the incentive target, incentive process and incentive methods and other aspects to consider. Among them, the incentive object mainly refers to practice teachers, teaching assistants, lecturers, associate professors and professors, including all faculty. Incentive process refers to the whole career of teachers in school, and adopts different incentive policies at different stages. The motivation method refers to the combination of rewards and punishments and performance, short-term motivation and long-term incentive in the implementation of incentive policies for teachers.

\section{B. General design idea of incentive system}

To the teachers individual needs as the starting point, to mobilize the enthusiasm of teachers as the direct purpose, design all kinds of external teachers' salaries, bonuses and other material rewards and intrinsic honor and title spiritual rewards, so as to form a set of incentive factors, meet external and internal demand of teachers, only to meet the individual needs of teachers, to put more effort on the job, the enthusiasm of the teachers only to be mobilized, sustainable development, in order to achieve positive.

After the construction of incentive system is completed, it is necessary to consider whether it can bring the best incentive effect. Only when the incentive effect is maximized can the whole incentive system be meaningful. The standard of measurement, however, is the best incentive effect that the system can achieve at the expense of the lowest cost [10].

\section{Efficiency improvement of school}

The function of school is teaching time allocation execution, but also the teaching quality control supervisor. The main function in the teaching time distribution management system for the link, not only need to accept the guidance of national policy, the English education policies are absorbed and transformed into school with a unique curriculum system, but also need to supervise and guide the teacher's teaching task the English teacher to complete the teaching goal and the course under the condition of high efficiency requirements.

The school is the top-level organization for the specific allocation of teaching time, which also requires schools to fully investigate and analyze the objectives of teaching tasks, and reduce the degree of dispersion of time use. There are two mechanisms which are conducive to the allocation of teaching time in schools: the circular system and the through system. The cycle refers to a continuous teaching for teachers of students, to facilitate the understanding between teachers and students, so that teachers can constantly adjust teaching methods according to students, improve students' sense of efficiency; through the system is single direction, let a teacher in charge of the English teaching such as reading and writing, so that special training to reduce the waste of time.

\section{Incentive system measures}

To the teachers individual needs as the starting point, to mobilize the enthusiasm of teachers as the direct purpose, design all kinds of external teachers' salaries, bonuses and other material rewards and intrinsic honor and title spiritual rewards, so as to form a set of incentive factors, meet external and internal demand of teachers, only to meet the individual needs of teachers, to put more effort on the job, the enthusiasm of the teachers only to be mobilized, sustainable development, in order to achieve positive.

Provide students with insufficient resources for internships and practices. The university as a teaching entity, its economic ability is limited, cannot provide the classroom outside more practice resources, as an important part of training applied talents, practice and essential. But as the main market of social enterprises or other institutions, for reasons of their own economic interests, it cannot provide practice resources for the majority of students, leading to the stage many school practice and keep up with classroom teaching and festival, a mere formality. Actively looking for and practice of the development of internal and external resources for students, it is particularly important in the process of cultivating applied talents in the new form, which requires schools to explore campus practice, practice on the one hand, such as "practice", "simulation practice" and other activities, to ease the practice of resource situation; on the other hand, the school should be oriented to social integration, actively seek cooperation mode, for the students to open up more, practice resources more practical, better solve the contradiction. 
Increase the incentive salary appropriately, make it occupy a certain proportion in the overall structure of the wage structure, and encourage the salary mainly refers to the quarterly appraisal, the scientific research achievement and the outstanding performance teacher's fund reward. This way you can make teachers through their own efforts to obtain the corresponding reward fund, embodies the basic principle of "hard work".

\section{CONCLUSION}

With the research of "Exploration of College English Teaching Reform in Application-oriented Universities", the application-oriented undergraduate education as the main part and the assistance of skilled higher vocational education is studied and it is quite useful for the development of master's degree and graduate education. The incentive system is introduced in the paper and it is necessary to consider whether it can bring the best incentive effect. Only when the incentive effect is maximized can the whole incentive system be meaningful. According to the results, the college English teaching reform will be improved effectively.

\section{ACKNOWLEDGMENT}

The paper is funded by the topic of "Research on the Reform of College English Teaching under the Mode of Combining Learning with Working" from Shandong Provincial Education Department with the number of EA201106.

\section{REFERENCES}

[1] Topkaya E Z, Uztosun M S. "Choosing Teaching as a Career: Motivations of Pre-service English Teachers in Turkey," Journal of Language Teaching \& Research, 2012, pp.126-134.

[2] Wati H. "The Effectiveness of Indonesian English Teachers Training Programs in Improving Confidence and Motivation," Internationa Journal of Instruction, 2011,pp.79-104.

[3] Sumru Akcan, Sibel Tatar. "An investigation of the nature of feedback given to pre - service English teachers during their practice teaching experience," Teacher Development, 2010, pp.153-172.

[4] Marie-José Guilloteaux. "Motivational strategies for the language classroom: Perceptions of Korean secondary school English teachers," System, 2013, pp.3-14.

[5] Trent J. "The Discursive Positioning of Teachers: Native-Speaking English Teachers and Educational Discourse in Hong Kong," Tesol Quarterly, 2012, pp.104-126.

[6] $\mathrm{Hu} \mathrm{Z}$, Mcgrath I. "Integrating ICT into College English: An implementation study of a national reform," Education and Information Technologies, 2012,pp.147-165.

[7] Gao F. "What's Wrong with Current Chinese College English Assessment System? Reform or Not?" International Education Studies, 2010, pp.34-37.

[8] Wang X F, Davies M, Liu G H. "A Good Platform for English Teachers and Learners:the Corpus of Contemporary American English(COCA)". Computer-Assisted Foreign Language Education in China, 2008, pp.215-218.

[9] Medgyes P. Nonnative. "Speaker English Teachers: Research, Pedagogy, and Professional Growth". ELT Journal, 2011, pp.210-212.

[10] Negretti R, Kuteeva M. "Fostering metacognitive genre awareness in L2 academic reading and writing: A case study of pre-service English teachers". Journal of Second Language Writing, 2011, pp.95-110. 